\title{
THE MYTHOLOGICAL ELEMENT IN VIRGINIA WOOLF'S THE WAVES: BERNARD'S VISION
}

Dennis Young

READERS AND CRITICS of Virginia Woolf seldom, if ever, discuss the religious dimension in her writings. Woolf's atheism (or "agnosticism") perhaps prevents her readers from perceiving the religious attitude in her work. While it is true that Woolf admits her distrust of organized religious answers, it is also true that she expresses a deeply mythic or religious (I use the words interchangeably) view of life in her art.

Of all Woolf's novels, The Waves comes closest to expressing a mythic vision of life. Her interest in the androgynous artist; her attention to "moments of being"; her passion for finding a true self in the flux of time; her use of symbols to express a complex, spiritual vision: these elements in her writing combine to create a mythic vision. The characters, though they are historically bound, achieve symbolic universality in their soliloquies. Bernard, one of the seven characters in the book, is Woolf's expression of the artist in quest of a total vision of life. We see Bernard, the "phrasemaker," in the process of coming to terms with his Self within the flux of time. Significantly, he utters the first and last words of the novel. In the final soliloquy, he expresses the summary statement. "Now to sum up . . . Now to explain to you the meaning of my life." Thus he begins his last utterance. He speaks "freely" of the "illusion . . . that something adheres for a moment, has roundness, weight, depth, is complete. This, for the moment, seems to be my life. If it were possible, I would hand it to you entire" (p. 238). Earlier he says: "We are the creators. We have made something that will join the innumerable congregations of past time" (p. 146). Bernard represents not so much a participant in this or that morsel of history, but spiritual entity, in the 
consciousness of being, rendering in his heavily stylized utterances the actual shock of experience.

Bernard embodies the androgynous artist Woolf describes in $A$ Room of One's Own. She says there:

One that has a profound, if irrational, instinct in favour of the theory that the union of man and woman makes for the greatest satisfaction, the most complete happiness. . . . The normal and comfortable state of being is that when [man and woman sides] live in harmony together, spiritually cooperating. If one is a man, still the woman part of the brain must have effect; and a woman also must have intercourse with the man in her. Coleridge perhaps meant this when he said that a great mind is androgynous. It is when this fusion takes place that the mind is fully fertilized and uses all its faculties. Perhaps a mind that is purely masculine cannot create, any more than a mind that is purely feminine. . . . Some collaboration has to take place in the mind between the woman and the man before the act of creation can be accomplished. Some marriage of opposites has to be consummated. ${ }^{2}$

The androgynous creator is central in Woolf's fiction, represented most obviously by Lily Briscoe in To the Lighthouse and Orlando in Orlando. (Septimus Smith and Clarissa Dalloway may also be said to represent the two aspects of the androgynous figure.)

Bernard, another androgynous creator, quotes his "biographer" as saying: "Joined to the sensibility of a woman . . . Bernard possessed the logical sobriety of man." A little later Bernard says: "Very few of you who are now discussing me have the double capacity to feel, to reason" (p. 76). And later: "For this is not one life; nor do I know if I am man or woman, Bernard or Neville, Louis, Susan, Jinny or Rhoda-so strange is the contact of one with another" (p. 281).

The androgynous being clearly has mythical connotations. By achieving the androgynous state, Bernard becomes more than man. For Woolf, the androgynous character enters a nearly symbolical realm where duality and social-role playing are left behind. This emphasis by Woolf points to her mythical sensibility, for androgynous figures are common in the world of myth. These figures emerge with a sense of mystery beyond objective experience. For example, the Great Original of the Chinese wisdom books, the holy woman T'ai Yuan, embodies the masculine Yang and the feminine Yin. They combine together to make manifest Tao: the source and law of being. The Buddha, another androgynous figure (often represented in Buddhist temples by the female deity Kwan Yin or the Japanese Kwannon), can transform into both male and female forms, and in effect transcends the duality of sex. The Hindu divinity Shiva appears united in a single body with Shakti, his spouse-he the right, she the left. Among the ancient Greeks not only Hermaphrodite (child of Hermes and Aphrodite) but Eros too, the divinity of love, were in sex both female and male. In biblical terms the removal of Eve from 
Adam into another form symbolizes the beginning of the fall from perfection into duality (and also the degeneration of eternal life into time-bound existence). ${ }^{3}$

There are similar examples in myth, religion, and folktale from all continents, but let it suffice to say that Woolf is not being merely fashionable when she says that the artistic temperament is fundamentally androgynous in its creative origin.

Bernard then is the androgynous, creative individual who, through the journey of his life, attains a perspective on the mystery of life. $\mathrm{He}$ discovers (or re-discovers) the symbols and language which carry the human spirit forward beyond the heart's life-weariness, so that he may face the challenge of death. While his friend Rhoda succumbs to what for her is the blissful lure of death, Bernard realizes that he must struggle against "the enemy." Bernard, by the end of the book, has moved full circle from the womb to the tomb (although we do not see his birth and death in the course of the novel). Just as the introductory italicized passages describe the full course of the sun's apparent movement, from obscurity to full light then back into obscurity and darkness, so Bernard makes an ambiguous, enigmatical incursion into a world of solid matter that is soon to fade away like the substance of dream.

Bernard must redeem himself from this world by embracing the "moment," a word he reiterates throughout the book, and one which Woolf herself expresses in much of her work. In Moments of Being Woolf suggests that "moments of being" are embedded in "moments of non-being." The "moment of being," nearly mystical in nature, occurs as a moment of epiphany or as "revelation of some order; it is a token of some real thing behind appearances; and I make it real by putting it into words. It is only by putting it into words that I make it whole."4

Bernard too finds the real behind the apparent, which he finds in "the moment" of revelation. "Let me touch the table-so-and thus recover my sense of the moment" (p. 267). "The moment was all, the moment was enough" (p. 278). Bernard too uses words to capture the moment. "I retrieved them from formlessness with words" (p. 270). He makes the moment "whole" with language: "I seek among phrases and fragments something unbroken. ..." (p. 266). The dozens of references Bernard makes to the "symbolical moment" need not be catalogued here. The important thing to remember is that capturing a "moment of being" involves the process of attaining something eternal and whole out of the flux of time, a basically religious impulse, one which Ernst Cassirer in Language and Myth calls a "mythicoreligious protophenomenon" or the "momentary god." Mythical 
thinking, Cassirer contends, "is captivated and enthralled by the intuition which suddenly confronts it. It comes to rest in the immediate experience, the sensible present is so great that everything else dwindles before it." This "momentary god" overwhelms the perceiving person with "sheer immediacy," the "subjective excitement becomes objectivified, and confronts the mind as a god or daemon." Cassirer's description of the mythico-religious "momentary god" approximates Bernard's concern for "the moment" throughout The Waves; Woolf's predominant attention to time and change in her writings again suggest her basically mythical-philosophical temperament.

Bernard seeks to redeem the flux of time by transcending it in an unbroken "eternal moment." He seeks a transcendent state "which is beyond and outside our own predicament . . . that which is symbolic, and thus perhaps permanent, if there is any permanence" (p. 248). Cassirer points out that a symbol in myth and art is not a mere figure which refers to some given reality by means of suggestion and allegorical rendering, but "appears as a force which produces and posits a world of its own." He goes on to say:

In [mythic and artistic realms] the spirit exhibits itself in that inwardly determined dialectic by virtue of which alone there is any reality, any organized and definite Being at all. Thus the special symbolic forms are not imitations, but organs of reality, since it is solely by their agency that anything real becomes an object for intellectual apprehension, and as such made visible to us. . . . For the mind, only that can be visible which has some definite form. . . .6

Bernard comprehends that in the symbolic willow tree by the river there lies an element of permanence. "The tree alone resisted our eternal flux" (p. 248). Here again, Woolf's choice of a tree as symbolic of permanence has mythical overtones. The tree here is highly suggestive, especially when one considers the various "trees" in the world of myth and religion, those "trees" which "resist eternal flux." One may recall Yahweh's tree of eternal life in Eden; Christ's cross, which is often associated with the tree of knowledge; the axial tree of the Old Norse Poetic Edda, Yggdrasil; Buddha's Bo tree under which s/he meditated while apprehending the "eternal moment"; the tree of American Indian myth (for example, Black Elk's eternal tree at the center of the nation's hoop as recorded in Black Elk Speaks).

The precedent of the willow tree in world myth adds a deeply mythic significance to Bernard's symbolic willow tree. Hugo Rahmer, in Greek Myths and Christian Mystery, devotes a lengthy section of his study to a discussion of the mythological significance of the willow tree in Greek and Roman myth, as well as in Christian symbolism. The willow tree becomes symbolically important in The Odyssey when Odysseus enters a realm in Hades between life and death (Book 11 of 
The Odyssey). In Greek myth the willow is "a symbol of fresh and bubbly life, and also the womb of death to which all things return."7 What the ancients especially admired in the willow tree was "its indestructible power of growth. Without the aid of man it continually bursts into new leaf." 8 Virgil is quoted in Georgics: "Without human aid they grow up, by their own power." 9 In fact the word "willow" is reputed to be derived from this quality of self-regenerative growth.

The willow, according to Rahmer, finds its way into Christian symbolism.

The willow, water-loving and yet fruit destroying . . . became for the Hellenistic Christian the symbol of those Christian mysteries which only unfold the full abundance of their life after death, but nevertheless send forth their roots even in this present world where men, both mystically and in fact, have still to die. Hence life and death are still united as in a bud and mutually condition each other. . . . The willow-tree that stands at this borderland of death, fruitless and yet living, is the mysterious symbol of this Christian dialectic. ${ }^{10}$

The willow of the Homeric underworld becomes in Christian symbology the "blessed, deifying tree."

As Joseph Campbell points out in The Mythic Image, "In many cases the 'tree of life' is conceived as an axis (axis mundi) extending vertically to the pole star and downward to some pivotal point in the abyss."11 Bernard's mythic identification, through an act of identity with the ground of existence, is enacted in memorable moments of awe and conviction associated with the willow tree. The basic element responsible for this mythic identification is EROS. Carl Jung describes eros as "a kosmogonos, a creator and father-mother of all higher consciousness." 12 The title of the book, The Waves, suggests the characters' mythic relationship to the "womb of the mother-goddess," with which the sea is often associated. The mother-goddess becomes the source of regeneration. The image of the waves suggests a world created not in the way of an act at the beginning of time, but continuously, forever, as the ground of all existence; for there never was a beginning of time, there will never be an end, the creative moment is now, as Bernard continuously recognizes, and which Woolf suggests with her dominant imagery of the waves and the movement of the sun (in the italicized passages).

Bernard is left with the problem of attaining Selfhood within the time-bound world of flux and change, represented by the image of the waves, yet he seems not to be concerned with attaining a distinct and separate individuality. Bernard recognizes the danger of the separate personality while seeking the solitude necessary for true Selfhood. $\mathrm{He}$ must have others for his words to have meaning. He must have others for his Self to exist. "We use our friends to measure our own stature" (p. 90). His life represents a dialectic between having many selves and 
having one Self. The question of Selfhood is for Bernard intimately bound up with the question of language because it is through language that the Self connects to the world, to others: the artist creates the world when he creates stories. Bernard wonders: "Am I all of them? Am I one and distinct? I do not know" (p. 288).

Bernard says: "What I call 'my life,' it is not one life that I look back upon; I am not one person; I am many people. . . . ." Bernard realizes he must think for himself, peer through his own eyes, heed the compass of his own heart and his own art. "If I could measure things with a compass I would, but since my only measure is a phrase, I make phrases" (p. 277). We have seen, in the course of his journey, Bernard following Byron, Bernard following Shelley, Bernard following Dostoevsky; finally, he follows no one but himself. "I was the inheritor; I, the continuer; I, the person miraculously appointed to carry it on" (p. 253). It appears that the Self, released from the matrix of inherited social bondages, can be attained, and Bernard sees that, in fact, it has been attained many times: specifically by those giants of creative thought, those "divine specifics," as he calls them. "Am I all of these? Am I one and distinct? . . . I cannot find any obstacle separating us. There is no division between me and them. This difference we make so much of, this identity we so feverishly cherish, was overcome" (p. 288). During such moments in Bernard's awareness, he expresses the genial and mystic themes of the lovely world of a paradise neither lost nor regained but ever present in the depths of his being. Having let his imagination be roused by the power of language, having learned the grammar of the soul, Bernard follows the echoes of his eloquent soliloquies, each echo opening a way to his ultimate seat of silence.

Avrom Fleishman points out that Bernard ultimately assimilates the point of view of the italicized passages. This assimilation suggests Bernard's recognition that he is not a separate personality, and we recognize in this paradoxical situation the essence of the teachings of the Orient. It is best expressed in the Sanskrit formula: Tat tvam asi ("that is you"). ${ }^{13}$ The idea is stated in the Bhagavad Gita:

Even as a person casts off worn-out clothes and puts on others that are new, so the embodied Self casts off worn-out bodies and enters into others that are new. Weapons cut It not; water wets It not; the wind does not wither It. This Self cannot be cut nor burnt nor wetted nor withered. Eternal, all pervading, unchanging, immovable, the Self is the same for ever. (Bhagavad Gita, 2:22-24) ${ }^{14}$

Tat tvam asi then insists that the essence of oneself is one, not two. Hence, separateness, withdrawal, is no longer necessary. Bernard confronts this question of Selfhood throughout his soliloquies; finally he realizes that he is ever in the presence of his own essence-for he has the artist's eye to see. There is no separateness. His social 
participation with his companions leads in the end to a realization of the All in himself; his exile brings him to the Self in all.

Bernard's goal is not to realize the unique possibilities of his temporal embodiment, but on the contrary, to become completely devoid of the sense of "I" and "mine." He seeks transcendence, release, from the deluding attachments to this world. He seeks oneness with the ocean of the Cosmic Self (brahmatman), which is at once the nothing and the all. ${ }^{15}$ But Bernard is torn between individuation and self-obliteration. One might say that Bernard is caught in the conflict between the Western sense of self and the self as understood in Eastern thought. Carl Jung writes: "In Eastern texts the 'Self' represents a purely spiritual idea, but in Western psychology the 'self' stands for a totality which comprises instincts, physiological and semi-physiological phenomena." 16 The Western sense of self is exactly the "clothes" that the central, immortal "Self" puts on and casts off.

The Eastern notion of "Self" (though foreign to the Western mind's nearly obsessive concern with the time- bound problems of personality and ego) I believe is at the heart of Bernard's struggle. Bernard involves himself in the dialectic between unity and multiplicity. While modern, rational man employs reason and logic to discriminate and divide the world, the Eastern wisdom books point to the identity of all things. In reference to Bernard and his six other friends, he says: "I do not believe in separation. We are not single. Also I wish to add to my collection of valuable observation upon the true nature of human life" (p. 67). "All divisions are merged-they act like one man" (p. 67).

Even though Bernard is a "phrasemaker," a storyteller, he distrusts language. Bernard insists that the speech act is not enough if one wishes to have true understanding. He must become receptive, even ego-less, in order to "embrace the whole world." At times Bernard seems to echo Lao-tze: "He who speaks does not know. He who knows does not speak." 17 Bernard says:

I wish to go under; to visit the profound depths; once in a while to exercise my prerogative not always to act, but to explore; to hear vague, ancestral sounds of boughs creaking, of mammoths, to indulge impossible desires to embrace the whole world with the arms of understanding impossible to those who act (114). ${ }^{18}$

Similar teachings are to be found in the Bhagavad Gita, where non-action is recommended in order to achieve the Godhead (or what Bernard calls "embracing the whole world"):

The world is imprisoned in its own activity, except when actions are performed as worship of God. Therefore you must perform every action sacramentally (as if it were yajna, the sacrifice that, in its divine Logos-essence, is identical with the Godhead to whom it is offered), and be free from all attachment to results. ${ }^{19}$

Although the terminology is different, the impulse is fundamentally the same. Both encourage non-activity (Bernard often calls it "si- 
lence") as a way of perceiving and experiencing the unity and wholeness of the world. All the masters of spiritual life, from the authors of the Upanishads to Buddha to Socrates, are agreed that without self-knowledge there cannot be adequate knowledge of God, that without a constant recollectedness there can be no complete deliverance from the bondage of the time-bound world. Bernard is such a person who has learned to regard things as symbols and is aware of himself as a man who stands in relation to the spiritual world. "I am aware of our ephemeral passage" (114). He is also aware of his connection to the eternal in Nature.

That Bernard's imaginative powers have been with him all the time is made evident by the language and images associated with him. $\mathrm{He}$ speaks the opening line of the novel: "I see a ring hanging above me. It quivers and hangs in a loop of light" (p. 9). The figure of the circle or ring becomes a leitmotif for Bernard's entire life and points to the structure of the book as a whole. He refers constantly and in various ways to the image during the course of his life. Bernard as a young man envisions a mystical, unknown land called "Elvedon," a place enclosed by a "ringed wood with the wall around it" (p. 17). Later in his life he confesses: "I am almost whole now" (p. 67). In one of the more memorable passages in the novel Bernard reflects on his various friends at a party, describing them in the image of a flower: "A single flower as we sat here waiting, but now a seven-sided flower, manypetaled, red, puce, purple-shaded . . - -a whole flower which every eye brings its own contribution" (p. 127). The circle imagery continues throughout the book. In the final soliloquy Bernard says: "The mind grows rings. . . . I seek among phrases and fragments something unbroken" (p. 257). Words are associated with rings of smoke: "When I cannot see words curling like rings of smoke round me I am in darkness- I am nothing" (p. 132). The self ("being") too is described in terms of the circle: "The being grows rings, like a tree" (p. 283).

The Jungian psychologist would explain the circular imagery as a symbol of the Self. The circle expresses the totality of the psyche in all its aspects, including the relationship between man and nature. ${ }^{20}$ The symbol of the circle appears in primitive sun worship, modern religions, mandalas of the Orient, myths of all places—always pointing to the vital aspect of life: its ultimate wholeness. (Plato too describes the psyche as a sphere.) The mythic overtones are clear enough. For example, the halo associated with angels in Christian teachings corresponds to wholeness and purity of spirit and heart. Dante, in the final Canto of The Divine Comedy, represents the trinity by imagining 
three circles converging in one circle with Christ at the center of the circle.

That light supreme, within its fathomless

Clear substance, showed to me three spheres, which bare

Three hues distinct, and occupied one space,

The first mirrored the next, as though it were

Rainbow from rainbow, and the third seemed flame

Breathed equally from each of the first pair. ${ }^{21}$

Not only do we find the circle imagery in Christian symbolism, but it is also present in Eastern mythology. Again the circle represents the wholeness and purity of the spiritual world. An Indian creation myth relates that the God Brahma, standing on a huge, thousand petaled lotus, turned his eyes to the four points of the compass. A similar tale is told of Buddha. At the moment of his birth, so the story goes, a lotus flower rose from the earth. His personality and life were given the imprint of wholeness. ${ }^{22}$

The image of the circle is integral to Eastern, Western, and Primitive myth and folktale, and must have had for Woolf a deeply mythic and psychological meaning. Her interest in the circle as a central symbol in many of her writings suggests both her androgynous leanings and her need to unify the temporal, personal world of the ego with the non- personal, timeless world. And, indeed, in Moments of Being, Woolf records a "moment," an "exceptional moment," which made such a lasting impression on her that she remembered it all her life.

I was looking at a plant with a spread of leaves; and it seemed suddenly plain that the flower itself was part of the earth; that a ring enclosed what was a flower; and that was the real flower; part earth; part flower. . . . When I said about the flower "That is the whole," I felt that I had made a discovery. I felt that I had put away in my mind something that I should go back [to], turn over and explore. ${ }^{23}$

Woolf has undoubtedly "turned over and explored" this image in her novels, and, as it happens, the ring becomes a central figure in terms of both the form and the content of The Waves.

Although Virginia Woolf reveals a religio-mythic orientation in her writing, it must be emphasized that she is working outside of any doctrinaire religion. Bernard is not a religious mystic in the usual sense of the word. Bernard is not even fully conscious of his role. He does not know toward which he moves. He does not know by what he is propelled. "For myself, I have no aim. I have no ambition. I will let myself be carried on by the general impulse" (p. 113). Yet, as artist, Bernard seeks to bring to light again the lost paradise of the whole, coordinated soul, the coordinated soul represented by the ring and circle. The problem Bernard (and Woolf) faces is nothing if not that 
of rendering the world, his life, spiritually significant-or, to put it another way, nothing if not that of making it possible to come to full humanity through the conditions of contemporary life, the life he shares with his companions.

Like Buddha, with the sword of his mind Bernard has to pierce the bubble of the many masks he has assumed, and thereby shatter them into nothing. But the miracle is that though all his masks explode, all is thereby renewed, revivified, awakened. On the very last page of this wonderful novel, Bernard says: "Yes, this is the eternal renewal, the incessant rise and fall and fall and rise again. And in me too the wave rises" (p. 297). The dawn is on the horizon, though not yet here. Bernard, to use the words of Nietzsche, learns to "live, as though the day were here."

\section{NOTES}

1 Virginia Woolf, The Waves (New York: Harcourt Brace Jovanovich, 1931), 238 (all subsequent references to the The Waves will be indicated by the page number from this edition).

2 Virginia Woolf, A Room of One's Own (New York: Harcourt Brace Jovanovich, 1929), 102 and 108.

3 Joseph Campbell, The Hero with a Thousand Faces (Princeton Univ. Press: Bollingen Series, 1949), 153.

4 Virginia Woolf, Moments of Being (New York: Harcourt Brace Jovanovich, 1976), 71.

5 Ernst Cassirer, trans. Susanne K. Langer, Language and Myth (New York: Oxford University Press, 1946), 62.

6 Cassirer, 63.

7 Hugo Rahmer, trans. Brian Battershaw, Greek Myths and Christian Mystery (New York: Harper and Row, 1963), 290.

8 Rahmer, 292.

9 Rahmer, 292.

10 Rahmer, 299.

11 Joseph Campbell, The Mythic Image (Bolingen Series C, Princeton University Press, 1974), 190

12 Carl Jung, trans. Richard and Clara Winston, Memories, Dreams, Reflections, (N.Y.: Pantheon Books, 1963), 353-354.

13 Aldous Huxley, The Perennial Philosophy (New York: Harper and Row, 1944), 2.

14 Campbell, The Hero with a Thousand Faces, 7.

15 Joseph Campbell, The Masks of God: Creative Mythology (New York: Penguin, 1957), 481.

16 Carl G. Jung, trans. R.F.C. Hull, Psychology and Religion (New York: Pantheon Books, Bollingen Series XX, Vol. II, 1958), 502.

17 Huxley, 216.

18 I am reminded here of Nietzche's Thus Spoke Zarathustra when Zarathustra speaks to the sun: "For I must descend to the depths, as you do in the evening when you go behind the sea and still bring light to the underworld. Like you, I must go under-go down-as is said by men, to whom I want to descend.”The Portable Nietzsche, trans. Walter Kaufman (New York: Penguin, 1957), 122.

19 Huxley, 272.

20 Carl G. Jung, Man and His Symbols (New York: Doubleday, 1964), 240. 
21 Dante (trans. John Ciardi), The Divine Comedy (Paradise Canto XXXIII), 11. 115-120. 22 Jung, Man and His Symbols, 240.

23 Woolf, Moments of Being, 70. 